\title{
Colonial retreat and maintenance
}

\section{TWO PORTS IN DECLINE}

The hectic final days of Von Plüskow were witness to the deepest humiliation yet of the Estado da Índia and the illusory triumph of the VOG. In the following years, however, both entities led a troublesome existence, exhibiting apparent difficulties in co-opting their clients. Unlike its Portuguese counterpart, the VOC port was not seriously threatened, but it was increasingly clear that its former role as the site of a stranger king could not easily be translated on a Timor-wide level given the obvious difficulties in forging an effective political network. This role, on the other hand, is one that the monarchy of Portugal had occupied for many years: a network underpinned by politico-religious symbols helped the Estado to survive against seemingly overwhelming odds.

From a Dutch as well as from an indigenous perspective, there could hardly have been a worse successor to Von Plüskow. Johan ter Herbruggen (gov. 1762-1765) seems to have easily been the most covetous and corrupt opperhoofd of the VOC period. The Timor documents from the mid-1760s abound with stories detailing his extortion of local princes and townsfolk. The five original allies nevertheless remained fundamentally loyal to the VOG. They now carried an official rank that was higher than the more populated domains of the interior, and when the Dutch offered the rulers the title of Don (Dom) like those of the formerly Portuguese lands, they proudly declared that they had no need for Portuguese titles. It was quite another matter, however, with the recent allies made inland. Latent dissatisfaction with the Company system came to a head with a series of uprisings during the time of Ter Herbruggen's successors. ${ }^{1}$

\footnotetext{
Ter Herbruggen also sent a pirate-like expedition to Sumba, which alienated the chiefs of that island from the Company (VOC 3251 [1769], f. 744).
} 
The extraction of gold from the rivers was an unpopular burden for the Sonbai of the interior to carry. Accidents occurred and the sub-rulers feared for their own safety, since the kinsmen of the casualties would rather turn their anger towards them than towards the Dutch. ${ }^{2}$ The project soon became loaded with danger from another quarter. The usif of Mollo was an Oematan, as was the regent family of Lesser Sonbai, and after the Battle of Penfui he was assumed to be subordinate to the emperor of this princedom. ${ }^{3}$ He nevertheless acted in a fiercely independent manner, carrying out massacres in various gold-mining camps in 1765 and 1767. The precise cause of these deeds remained unclear to the Dutch, but there were ominous rumours that the Sonbai dynasty itself was involved. ${ }^{4}$ If the intention was to guard the Sonbai inland from the covetous Dutch then it turned out to be very successful. The then opperhoofd, Alexander Cornabé (gov. 1767-1772), had no means to avenge the last massacre, and the gold-mining project ceased completely by circa 1770 (Müller 1857, II:138-9). Indeed, after Von Plüskow, no VOC opperhoofd took the trouble to travel inland, complete with all its dangers.

The weakness of the Company was similarly demonstrated by Timau, the area of Amfoan that lay on the north coast. When King Dom Bernardo da Costa died in a skirmish in 1753, he was succeeded by his brother Tusala. Whilst initially praising Tusala for a number of virtues the Dutch soon changed their opinion when he began to engage in anti-VOG activities. In 1767, shortly after he had committed some particularly bloody acts against the Company allies, he was suddenly pardoned by the opperhoofd. In much the same way as previous instances, the Company again realized that they had no power to punish determined opponents, as Cornabé himself admitted. One reason as to why Kupang was so powerless, was that few Dutch troops could be allocated to such an unprofitable island. After 1733, malaria killed off a large proportion of incoming Europeans to Batavia, which suddenly made Kupang the healthier place to be. All of this affected the VOC's ability to staff the outposts in the archipelago or to organize military expeditions. ${ }^{5}$

While Dutch power in West Timor declined, the Portuguese sphere

$2 \quad$ VOC 3473 (1777), ff. 515b-516a.

$3 \quad \operatorname{VOC} 3473$ (1777), f. 515b.

$4 \quad$ VOC 3151 (1765), ff. 11-3; VOC 3215 (1767), ff. 665a.

$5 \quad$ Van der Brug 1994:155; Jones 2003:44. The mortality rate for Batavia in 1768/69 was 36\%, for Banten 19\%, for Cape Town 17\% and for Timor 6\%. In Indonesia, only Makassar had lower death rates. 
fell into chaos, reminiscent of the situation in the early eighteenth century. In the wake of the Von Plüskow affair, a number of interim juntas attempted to govern the 'colony'. A central figure in the somewhat confused political situation of the 1760s was the Oecusse leader, Francisco Hornay III. Through the murder of Von Plüskow, his Topasses had probably regained much of the military prestige that they had lost in 1749 (Andaya 2010). Francisco Hornay was a sly yet enterprising figure who was guided by his activist mother, Dona Agostinha. This lady was, according to the Lifau government, 'the person who foments and has always fomented all the wicked things and machinations against this port and all the royal domains on these islands' (Castro 1867:260). Hornay briefly joined one of the juntas in 1762-1763 but then had a fallingout with his colleagues and withdrew. In May 1766, he openly rebelled against Lifau, and in July of the following year he attacked the port. ${ }^{6}$ The conflicts that were apparent in these years cannot simply be reduced to the old White versus Black Portuguese dichotomy. Hornay made overtures towards Alexander Cornabé and asked for protection and assistance against Lifau, but not every Topass appreciated his venture. The Company was still perceived as the antithesis of both Portugal and the true religion, and the Da Costas preferred instead to maintain contact with the Lifau government, leading to a situation where the Topass group was temporarily split into two camps. ${ }^{7}$

Matters came to a head in 1768 when a new regular governor sailed to Timor. This was António José Telles de Meneses (gov. 1768-1776), who had gained much experience as an administrator in Mozambique and Macao. His arrival coincided with the death of Raja Dom Gaspar of Larantuka, who favoured the Estado da Índia. It was only by this time that the native rajas of Larantuka had become both active and resourceful rulers, at roughly the same time as the Hornays and Da Costas confined their activities to Timor. The new raja, Dom Manuel was in favour of the Topasses and sent auxiliaries to Hornay, who by now had blocked Lifau. The Dutch described the struggle as a showdown between the White and Black Portuguese that could only possibly end with the destruction of one or other of them. ${ }^{8}$ There was bitter personal resentment against the whites, who arrested 23 prominent Topasses when they

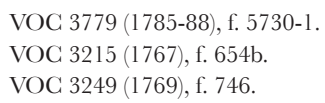


came to negotiate. The Lifau fortifications were too strong to be taken by assault, but Hornay managed to block the port from the land as well as the sea. The Da Costa brothers Domingos and António joined Hornay in the enterprise. ${ }^{9}$

Finally António José Telles de Meneses realized the impossibility of beating the hostile onslaught. He was responsible for 1,200 people in Lifau, including slaves, and there was no way of protecting them. Subsequently he resolved to give up the post that he had endured for 67 troubled years. During the night of 11 August 1769, he put artillery and inhabitants into the available boats, set fire to all the buildings and left in haste. ${ }^{10}$ During the siege Francisco Hornay sent envoys to tell Cornabé that he may well consider turning Lifau over to the VOC. Similar words had been uttered eight years previously, with a now wellknown result, and Batavia as well as Amsterdam reiterated their wish not to get involved with the internecine Portuguese troubles. Such an action would only be interpreted as trouble, trouble that was likely to outweigh the benefits of such a mission. After Francisco Hornay had taken Lifau he declined to follow up the previous offer. ${ }^{11}$ His relations with Kupang nevertheless remained good, and - if a somewhat later Portuguese text can be trusted - his party swore a blood-oath with the Company and was given back the head of Gaspar da Costa, slain twenty years earlier, an important symbolic gesture. ${ }^{12}$

The Topass victory, however, was hollow. The reward for the lengthy siege was a burnt-out settlement with little or no booty to be had. The Topasses kept an area of land centred in Oecusse, plus the highland enclave of Noimuti, as well as concluding a symbiotic relationship with the original lords of the land of Ambeno. The Hornay or Da Costa leader was henceforth known as king or raja of Oecusse, indicative of an ongoing indigenization and a change from the early colonial economic structures. These structures, which also exhibited precolonial features, had in the past included coercive trade with local polities, and had been

\footnotetext{
9 Matos 1974a:438. The Da Costa brothers were among those 23 people imprisoned in Lifau. According to a Dutch source seen by Boxer (1947:16), these people were executed by Telles de Meneses. De Rosily's account from 1772 nevertheless indicates that Domingos da Costa survived (Lombard-Jourdain 1982:93).

10 Telles de Meneses's own account of this is found in Castro 1867:252-3.

$11 \quad$ VOC 8301 (1772), ff. 25-6.

12 VOC 3779 (1785-88), f. 5732 . The issue of winning back the heads of slain rulers is a theme in Timorese oral tradition (Parera 1994:190-3).
} 
based on political dominance over wide territories. These times, however, were now over, and the very word 'Topass' seems to have disappeared from usage in the nineteenth century. ${ }^{13}$ The Dutch impact was no doubt a principal reason for the declining Topass fortunes - in spite of the Dutch experiencing their own difficulties. While some new allies of the Company became unwilling and even defected, they did not return to the Topass network. ${ }^{14}$ The old military advantage of the mestizos was lessened by the dissemination of firearms among indigenous groups. The incomes derived from sandalwood, beeswax and slaves that co-operation with the West Timorese domains had engendered before 1749, did not reappear. Larantuka and Sikka on Flores retained a (mainly Black) Portuguese attachment, and the rajas of Larantuka had matrimonial ties with the Hornays. ${ }^{15}$ Nevertheless, the indigenous Florenese rajas rather than the Hornays and Da Costas ruled the former Portuguese stronghold after the 1760s. Trade on Timor by the late eighteenth century onwards was dominated by Chinese people whose flexible approach to business replaced the older structures. Global trade quickened during the same period and with it the Chinese junk trade in Southeast Asia. Although the junk trade to Batavia declined, the Chinese staying in, or going to, Timor stabilized their position. ${ }^{16}$

Furthermore, much of whatever influence the Topasses might have enjoyed in East Timor vanished with their seizure of Lifau. The royalist fleet led by Telles de Meneses made a stopover in Batugade and pondered upon the viability of a new permanent stronghold. In spite of the Lifau debacle, the East Timorese elites were not averse to receiving the White Portuguese in their land. While the siege was still in progress, they decided to settle at Vemasse, whose king, Dom Felipe de Freitas Soares, was attached to the Portuguese; this was the same Vemasse that was

\footnotetext{
13 Nineteenth-century European officials do not use the term in their reports, but rather speak of Oecusse people (Oeykoessiers). The term is nevertheless preserved in the ritual language in Amfoan and Oecusse (Hendrik Ataupah, Kupang, interview 27-11-2009).

${ }_{4}$ At best, they entered into temporary strategic alliances with Oecusse. Thus Nai To Oematan of Mollo, an usif subordinated to Greater Sonbai, quarrelled with the then emperor in 1798, and briefly co-operated with Pedro Hornay (ANRI VOC:4059, Missive, Batavia to Kupang, 2-3-1802). Mollo was soon inside the Sonbai sphere once again, however. The king of Ambeno, the original lord of the land, was closely related to the Hornays, but he, too, sent periodical gifts of homage to the Dutch authorities. As late as 1851, a prince of Ambeno visited Kupang (ANRI Timor:60, Kort verslag, sub 20-5-1851).

15 Castro 1867:212. Larantuka was still dependent on the Topasses around 1780 (Van Hogendorp 1780:97).

16 Schlicher 1996:100-2; Pan 1999:51-2; Gupta 2001:123; Lombard-Jourdain 1998.
} 
ravaged by Matheus da Costa in 1668. Although Vemasse offered good defences, Telles de Meneses finally decided upon Dili in the territory of the important Motael (Mota Ain) princedom. Dili, it will be remembered, served as a refuge for the White Portuguese in 1761. A new Portuguese stronghold was founded there on 10 October 1769. ${ }^{17}$

Dili offered more advantages than any other feasible alternative. It was unhealthy, but little attention was paid to this at the time. Coral banks protected the beach from the breakers, which made it the only place suitable to anchor large ships on the island. Kupang, Lifau and Oecusse are ports that are open to adverse winds (Castro 1862:474-5). Dili was surrounded by a sizeable plain suitable for rice cultivation, so that its hinterland could support a considerable population, and to the south were swampy lands that offered protection against native enemies. The king of Motael, Dom Alexandre Rodrigues Pereira, enthusiastically offered gifts to the Crown of Portugal: large fields and lands for cultivation, a supply of firewood, wood for construction, horses and men (Matos 1974a:98-9). Soon after they had settled at Dili, the majority of the rulers of the Province of Belu came to offer their homage to the governor; in that way, the fact that the royalist centre had moved to the east, served to tie the East Timorese domains to the Crown. In Dili, Telles de Meneses was present along with some 40 White Portuguese and a sizeable troop of sepoys, non-white soldiers trained in Western fashion, with most of them coming from Goa and Mozambique. Only at this point in time do we find clear evidence in the sources of the presence of soldiers from Portuguese Africa in Timor. ${ }^{18}$

\footnotetext{
17 Marques Soares 2003:44 relates some details about this process that were not found in published Portuguese sources, and were possibly dependent upon oral tradition. After fleeing Lifau, Teles de Meneses would have visited Kefamenanu and Kupang, before being expelled to Dili by the ruler of Sonbai. Dutch archival sources on the other hand indicate that Sonbai was, for once, not involved in this cataclysmic affair.

18 Lombard-Jourdain 1982:94. As we have seen, there were 'Kaffers' present on Timor at the time of António Hornay. There were Goa plans to provide reinforcements to the hard-pressed António Coelho Guerreiro by way of cafres in the early years of the eighteenth century, although in the end they do not seem to have reached Timor (Faria de Morais 1944:125). By 1813, out of a population of 1,768 in Dili, 688 were African slaves, which was apparently the result of the annual import of slaves from Mozambique to Portuguese Asia (Gunn n.y.:52-3).
} 
With the stirring events of 1761 and 1769, the stage was set for almost two centuries of colonial division. It was a division that was of practically no consequence for large groups of Timorese who had little or nothing to do with either the Dutch or the Portuguese. Still, the Battle of Penfui, the murder of Von Plüskow, and the transfer of administrative power from Lifau to Dili were events that provided the prerequisites for a redrawing of the political map in 1859, which was finalized in 1916, and again in 1999. We shall now take a brief look at the ways in which the two colonial entities managed to stabilize their respective spheres in the years leading up to the Napoleonic Wars.

The Atoni princedoms of Amanatun, Amarasi and Amfoan-Timau, and the Tocodede-speaking Maubara, enjoyed predominantly amicable relations with the Company during the last three decades of the century. Ambeno, as well as Belu (in its more restricted Central Timorese sense), continued in their vacillating stance and had occasionally written the annual native letter of homage to Batavia. Jean-Baptiste Pelon noted in 1778 that the princes on the south coast of the island would favour either Dutch or Portuguese traders, depending on the circumstances, but had not formed a steady attachment to one or the other. Ironically, this was the only area left on Timor where one could still obtain a good amount of sandalwood, the principal economic rationale behind the foreign presence (Pelon 2002:8-9). As the sandalwood stands along the coast continued to decrease in number, the price of sandalwood rose from 15 cents per pound before 1750 to 55 cents in the late 1780s. Timorese suppliers now tended to sort the wood according to its quality rather than just sell it at a single price. Under the right conditions, there were therefore still profits to be made, profits which were enhanced by the fact that the Chinese demand for sandalwood increased during this period because of the trade with China carried on by so called country traders. Moreover, in 1792 the Company tried to reduce the costs of maintaining the Kupang post by loosening the restrictions on the Timor trade (Jacobs 2000:35).

The major problem for the Dutch were the important inland realms of Greater Sonbai and Amanuban. The emperor Usi Ana, alias Albertus Johannes Taffy, passed away in 1768; according to the rumours, he 
had been poisoned. ${ }^{19}$ His young son Alphonsus Adrianus, or Nai Kau Sonbai, (1762-1802) was raised in the household of the opperhoofden in order to avoid the problems that haunted Dutch relations with previous emperors. The result, however, was not the outcome desired by the Dutch, according to the sombre judgement of opperhoofd Barend Fokkens: there was reason to fear that the youngster would develop the same ostensibly bad character as his father. ${ }^{20}$ To make matters more complicated, the young man inherited the lordship of Lesser Sonbai when that line expired in $1776 .{ }^{21}$ For the first time since 1657-1658 there was technically one single Sonbai realm, but the union was not destined to be a long or lucky one.

Later Dutch writers tended to blame the miserly opperhoofd Willem Adriaan van Este (gov. 1777-1789) for the Dutch-Sonbai break that subsequently followed. According to a well-known story told in the nineteenth century, the young Alphonsus Adrianus happened to overhear an ominous conversation between Van Este, an influential Chinese man and the emperor's governor and relative, Bernardus Nisnoni. The three men resolved to remove Alphonsus Adrianus from power in order to further their own ambitions. The emperor immediately mounted a horse and galloped out of Kupang, never to return. Instead, he found that he had followers in the highlands where the name of Sonbai was still held in high regard (Heijmering 1847:193; B. 1852:219; Veth 1855:708). Nothing of this kind is hinted at in the reports of Van Este himself, who only admits that the emperor secretly left Kupang for unspecified reasons, and that he initiated trouble inland in 1782-1783.22 Oral Timorese tradition, however, suggests a 'pull' rather than 'push' factor by way of explanation for the flight of Alphonsus Adrianus. The highland chiefs found the absence of a monarch in their territory distressing and sent a delegation to Kupang, which persuaded the young ruler to return with them (Middelkoop 1938:435; Fobia 1984:91-2). Regardless of the details, the Timorese perspective on the story is indeed plausible, since a symbolic central figure was no doubt needed to maintain the coherence of the Sonbai realm. In Alphonsus Adrianus, the highland Atoni received a lord who was an activist figure, and therefore quite atypical

$19 \quad$ VOC 3779 (1785-88), f. 8707.

2o $\quad$ VOC 3473 (1777), ff. 514b-515a.

${ }^{21} \operatorname{VOC} 3465$ (1776).

22 VOC 3649 (1783). 
of the traditional diarchy. In a sense he reinvented Sonbai and made it into an aggressive and even expansive polity that, for the first time in living memory, depended on neither the Dutch nor the Portuguese. His European upbringing may have influenced his rather intricate political manoeuvring, although he acted much like any Southeast Asian 'man of prowess'.

Gathering thousands of followers, Alphonsus Adrianus formed an alliance with Amfoan-Timau and Ambeno, and also with a dissatisfied prince from Amanuban called Tobani. With these supposed allies of the Company at his side he attacked Mollo, a Sonbai component which over the last few decades had followed an independent route, and plundered its almost impenetrable mountain stronghold of Kauniki. ${ }^{23}$ Adrianus' former governor, Bernardus Nisnoni, tried to talk him out of the enterprise via envoys, but to no avail, which was hardly surprising given his previous plotting against the young ruler. The emperor nevertheless continued to send gifts of homage to Kupang year after year, so that it seemed as if he were not really working against the VOC. In 1786 he allowed his troops to attack Dirma in the Belu area, which was under the control of the Dutch. He captured the loro and his family along with a booty consisting of cattle, horses and people. Some captives were sent as a present to Van Este, who was not amused. ${ }^{24}$ It seems that Alphonsus Adrianus made use of the simmering rivalry between Kupang and Dili, playing the two colonial entities against each other: Dili by this time had claimed Dirma as part of its territory and its governor, João Baptista Vieira Godinho, reacted angrily to the 'Dutch' incursion. In spite of his actions in Dirma, Alphonsus Adrianus made contact with a Portuguese padre who resided in Noimuti and who sold weapons to the Sonbai lord via Oecusse. The Dutch found out about this trade, which aroused their anger against the Portuguese. The following years saw a very heated exchange of letters between the two ports, with both sides accusing the other of acting in an outrageous and dishonest way. ${ }^{25}$

By this time, a state of open warfare existed between Sonbai and the Company. In 1786, Emperor Adrianus led an attack on the very heart of the area under direct VOC control, which cost the life of the king of Kupang, Kolang Tepak. Soon after this, his troops devastated the settle-

\footnotetext{
23 VOC 3674 (1784), ff. 5, 39; De Roo van Alderwerelt 1904:214.

${ }_{24}$ VOC 3779 (1785-88), ff. 5692-5.

${ }_{25} \quad$ VOC 3779 (1785-88), ff. 5705-6, 5749-51.
} 
ment of Pariti on the north-eastern shore of Kupang Bay. ${ }^{26}$ Captain William Bligh, who arrived in Kupang in 1789 after his remarkable sea trip, commented that the ravages committed during the war had brought about such a scarcity of provisions that the effects could still clearly be seen at the time of his stay. ${ }^{27}$ Finally Van Este took the less than heroic, but well-tried step of granting the emperor a pardon in 1788. This being done, Kupang reported to Batavia that everything on Timor was once again peaceful and in order. ${ }^{28}$

This was, however, not quite true. Greater Sonbai remained an autonomous entity that managed its own affairs, and Alphonsus Adrianus was never actually punished; he continued to reside on the fortified rock of Nefo a few days travel east of Kupang, until his death in 1802. ${ }^{29}$ After the outbreak of the Fourth Anglo-Dutch War in 1780, the Company suffered an acute financial crisis, which meant that unprofitable outposts became a low priority (Gaastra 2003). In these waning days of the VOC, there were clear indications of the level of impotency of the Dutch establishment, reminiscent of the worst days of humiliation suffered by the Portuguese Lifau government. In 1792, Alphonsus Adrianus intervened in a succession issue in Amabi and ravaged land that was loyal to the Company. The Dutch opperhoofd Timoteus Wanjon (gov. 1789-1797) was bewildered by the ferocious behaviour of a princedom that had just 'submitted' to VOC rule, but he could do little about it. At precisely the same time, Maubara, which doggedly remained a part of the precarious VOC system, came under severe threat from Oecusse and Ambeno, and this time Wanjon reacted quickly. He gave his blessings to Alphonsus Adrianus to intervene in Maubara, on the condition that it must not be known that Kupang was behind the enterprise; the governor in Dili should not be provoked more than necessary. In other words, Wanjon cunningly used the same ruler, who had just ravaged the

$26 \quad$ ANRI Timor:7, Algemeene missiven (1786); VOC 3787 (1787), f. 578a; VOC 3810 (1788), f. 41.

27 Miller 1996:65. A short Dutch account of the mutiny on the Bounty and Bligh's adventurous sea journey to Kupang can be found in VOC 3859 (1789), ff. 4-5.

$28 \quad$ VOC 3659 (1789), f. 76-9.

29 B. 1852:219 incorrectly asserts that Alphonsus Adrianus died in 1819, while an original Dutch source actually reports his death in early 1803, implying that it took place in 1802 (ANRI VOC:4059, Missive from Batavia to Kupang, 15-3-1803). A long letter that Alphonsus Adrianus sent to the Company in 1798 contains a circumstantial story about a conflict with the Oematan lord of Mollo (LOr 2238, UB Leiden; Raad der Aziatische Bezittingen1800-1806, No. 131, Nationaal Archief). Oral tradition also mentions that Nai Kau Sonbai (Alphonsus Adrianus) fell out with Kono-Oematan after he had killed two of their men, who were accused of having an illicit affair with his wife (Fobia 1984:92-3). 
land belonging to a faithful ally, to solve a problem for the VOG. The Dutch to all intents and purposes, made a virtue out of necessity and improvised their shaky Timor policy as far as was possible. In this case it worked, since the commanders of Oecusse and Ambeno mismanaged the operation, and Maubara remained affiliated to the VOC for the time being. ${ }^{30}$

In actual fact, Greater Sonbai held a degree of influence in Belu. Alphonsus Adrianus was reportedly the 'support and consolation' of the central Tetun regents by the 1790s. ${ }^{31}$ The Oecusse ruler Pedro Hornay, now at peace with Dili, attempted to tie these regents more closely to the Portuguese network by spreading a false rumour that the Sonbai lord had died. The fraud was soon discovered, and the Belu suggested that Alphonsus Adrianus join forces to attack the lands of Hornay, but Timoteus Wanjon advised against the adventure and strongly urged the emperor to keep the peace with Oecusse. Nevertheless, hostilities between Oecusse and Sonbai are known to have lasted until at least 1810, and to have had dire consequences for the Portuguese sandalwood trade. ${ }^{32}$ The contrast with the heyday of Topass rule is apparent, and confirms what is said in a Dutch report from circa 1819: the power of the Black Portuguese had receded greatly in recent times, and they were not nearly as feared as before. ${ }^{33}$

The active stance assumed by Alphonsus Adrianus also sparked off a few other cases of recalcitrance towards the Company. The Amanuban prince Tobani claimed a new position as ruler of the princedom, and used the 1786 warfare to attack the king, despite his Dutch support. The larger part of Amanuban henceforth acknowledged Tobani, who acted with great spite towards the Dutch. ${ }^{34}$ Especially under the leadership of his son Don Louis (r. circa 1808-1824), Amanuban developed into a belligerent power that managed to hold British and Dutch adversaries at bay in spite of several expeditions. In the same way, the important Belu realm of Fialaran denounced the VOG in 1786 and made contact with

\footnotetext{
3o VOC 3960 (1792), ff. 55-60; Castro 1867:291. In a letter of homage from 23-11-1798, the East Timorese domains Nusadila and Lanqueiro are also mentioned, together with Maubara, as being affiliated to the Dutch (Raad der Aziatische Bezittingen 1800-1806, No. 131, Nationaal Archief). In a treaty of 1859, the Netherlands finally ceded Maubara to Portugal. The takeover was implemented in 1861 (ANRI Timor:104, Kort verslag, sub 22-3-1861; Pélissier 1996:40).

${ }_{31}$ Comité Oost-Indische Handel en Bezittingen 1795, No. 102, Nationaal Archief.

$3^{2} \quad$ Comité Oost-Indische Handel en Bezittingen 1795, No. 102, Nationaal Archief; Castro 1867:213-5.

33 Iets over het eiland Timor, c. 1819, H 245a, KITLV.

34 For a legendary version of this, see Parera 1994:200.
} 


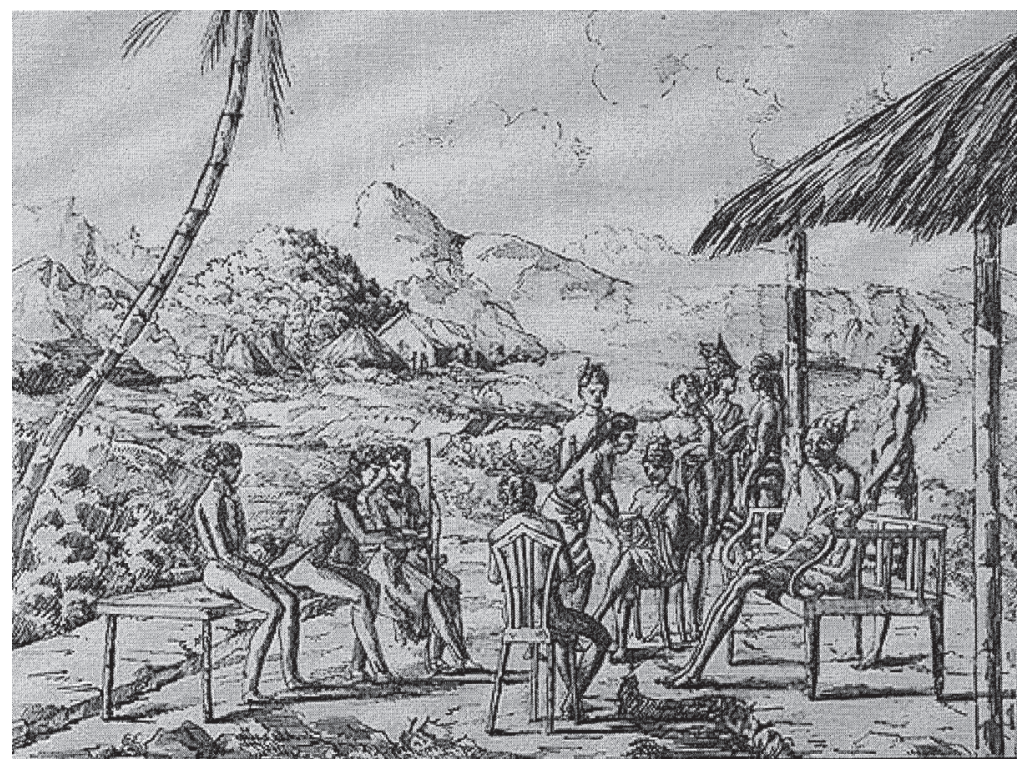

The Sonbai ruler Pieter Nube, who ruled in 1798-1821, with French visitors. Illustration by Jacques Arago, who followed the expedition of L.-C. Freycinet in 1818. This is the only known portrait of an early Sonbai ruler.

Dili, possibly because of the perceived level of Dutch impotency in the face of the Sonbai onslaught. ${ }^{35}$

During this era Greater Sonbai and Amanuban were contest realms, characterized by the atypical activism of traditionally inactive rulers. That their status was dependent on the personal qualities of their leaders is shown by their shifting fortunes during the nineteenth century. There was no real move towards state formation, but power was wielded through traditional channels, and relied upon alliances, wife-giving relations, and the Dutch unwillingness to penetrate the inland. ${ }^{36}$ Sonbai was split up between various usif in the early nineteenth century, and power had to be reassembled in a slow and cumbersome manner by the next

\section{$35 \quad \operatorname{VOC} 3767(1787)$.}

$3^{6}$ In the early nineteenth century, the king of Amanuban was considered 'the only one who has reduced any part of his subjects to a state of discipline'. He trained a large corps of horsemen armed with muskets, like the Pindaris of India, but the rapid decline of royal power after the death of Don Louis demonstrates the fragility of the system (Moor 1968:7-8). 
ruler, Nai Sobe Sonbai (reign 1808-1867). ${ }^{37}$ Towards the late nineteenth century, the wide but incoherent realm once again began to break up, and this time the onset of real colonial rule prevented its resurgence. In 1906, the last emperor was captured by Dutch troops, an act indicative of the definitive end of Greater Sonbai. After circa 1824 Amanuban, too, experienced long periods of fragmentation until it was finally brought under complete Dutch domination in 1906-1910 (McWilliam 2002:55-60; Farram 2003:74-9, 90-8; Farram 2009).

In spite of all these disturbances in the interior of the island, Dutch authority in the Kupang area remained intact, with the five loyal allies still forming a protective belt. After the flight of the emperor, the Lesser Sonbai princedom continued under the Nisnoni side-branch which, like the other four loyal allies, never questioned the Company's status as stranger lord up until the 1940s. When the French Revolutionary Wars reached the East Indies in the 1790s, this was demonstrated in a remarkable fashion. As a consequence of the Kew letters issued by the exiled Dutch stadtholder, British squadrons were dispatched to secure a number of VOG posts. A small British expedition approached Kupang in 1797 and tried to pressure Timoteus Wanjon and his council into capitulating without a fight, but the Company servant Carel Gratus Greeving refused to surrender. He met with the Sonbai, Amabi and Taebenu lords and asked their opinion about the situation. They replied: 'We rajas have the land and Tuan has the sea.' In a written statement the rulers commented, 'From that statement, Tuan could then see that we rajas in the land of Kupang have the Lord Company at heart'. ${ }^{38}$ The British soldiers who had been posted in Kupang were subsequently assaulted and massacred, and the expedition left after using the ship's artillery to reduce the town to rubble.

Similarly, a second British attack in April 1811 was defeated, mainly by Amabi marksmen who had been recruited by the Eurasian resident (commander) ${ }^{39}$ Jacobus Arnoldus Hazaart. It was only in January 1812

\footnotetext{
37 Although the concept of 'contest state' might be useful here, the denomination 'state' fails to cover the situation of Timorese princedoms (compare Henk Schulte Nordholt 1996:4-10). In the contest state, a complex of vertical relations between ruler and entourage had to be reconstructed with each succession. The power of Nai Sobe Sonbai as the heir of Alphonsus Adrianus was stabilized in 1808 (Timor:9, Missive from Kupang to Batavia, 10-9- 1808). However, his level of authority fluctuated greatly during almost 60 years of turbulent rule.

$3^{8}$ LOr 2242, 1798, UB Leiden; Meursinge 1845:xix-xx.

39 After the dissolution of the VOC in 1799-1800, the term resident is used rather than opperhoofd.
} 
that a British ship persuaded Fort Concordia to surrender without a blow, several months after the capitulation of the Dutch and French in Java (Farram 2007:461-6). After the return of the Dutch in circa 1819, a witness was intrigued by the scene in Kupang of allied kings greeting a visiting commissioner. They appeared at the meeting clad in costumes from the VOC period, and 'it was noted that when the name of the East India Company was still pronounced by them, it was done so with deep reverence'. ${ }^{40}$ That was two decades after the rather unspectacular end of the VOG.

The old system was maintained in a modified version during the nineteenth century, meaning that it was still 'early colonial' and built on reciprocity between foreign lord and indigenous allies. In a friendly conversation with a Dutch resident in the 1870s, the ruler of Amabi expressed no qualms about the symbiotic relationship between his princedom and the Dutch local government, nor about his own strong position in the system: 'If you are attacked yourself, and I do not assist you, then you will be rapidly put to the sword even if the other small rajas come to your help. But when I help you, you need not fear anything' (Schets 1877:339). As late as in the 1890s, according to a former controleur (local administrative headman), "the interior was still almost "terra incognita", the encounters that we had with the inhabitants were only sporadic and superficial and did not always leave the most pleasant memories. And in the $5 \%$ [of the territory] where we had a say, we did almost nothing. There was no question of roads and bridges, corvée labour, taxes, cultivation, and so on; we preserved the order as good or bad as could be, and that was that' (Grijzen 1923:466).

Certain theories of imperialism have noted a tendency among colonial powers to expand their influence informally until a relatively late point in time. Formal control was normally only implemented in times of absolute necessity, as when indigenous groups resisted the economic and political dispositions of the colonial overlords (Ardhana 2000:5-7). Timor, in the decades surrounding 1900, would be a case in point: from an economic point of view, the Timor area during the nineteenth century was characterized by a relatively open system in which several trading networks existed, operated by Indonesian, Chinese and Arab traders. After 1891, a regular line of Dutch government shipping began to alter 
the situation, and in the early twentieth century the old trading structures were subordinated to the colonial economic system (Parimartha 2008:75-7). In the meantime, economic change was matched by political restructuring. The two halves of the island now saw the colonial powers penetrate Timor further, which meant that the functioning of the five loyal allies as a protective belt, as rightfully pointed out by the king of Amabi, no longer existed. The consequences thereof were soon visible: in 1910 and 1917 these domains merged into a few zelfbesturende landschappen as part of a Dutch plan to rationalize local governance (Van Dijk 1925, 1934; Bongenaar 2005:23, 73, 358). Today the descendants of the old princely families lead modest urban lives in the lower-middleclass echelons, occasionally carving a minor career for themselves as a bureaucrat or local politician.

After 1769, the Portuguese establishment in Dili led a more stable existence than the old Lifau post, but it was still not approaching anything akin to a colonial power in the modern sense of the word. Alliances shifted rapidly back and forth, and a ruler who had recently adhered to the Company's rule, could suddenly decide to offer an oath of allegiance to the Crown. Thus some of the lords of the central Belu area were persuaded to come to Batugade in 1777 and offer their loyalty to Portugal once more ${ }^{41} \mathrm{~A}$ few cases of anti-Portuguese resistance occurred, especially in the important and influential domain of Luca during the late 1770s. Luca had hitherto usually supported the Crown of Portugal, but now a woman of prophetic qualities gathered the population, preaching that the ancestral spirits would assist the living, allowing them to shake off the yoke of the foreigners. This movement, which the Portuguese called the 'War of the Madmen', involved nearby domains and could not be entirely suppressed by the Dili administration. Nevertheless the neighbouring Viqueque stood firmly on the Portuguese side, as it had done 80 years previously. After several years the resistance ended in approximately 1785 , as had so many previous anti-foreign movements, with the voluntary submission of the local elite. ${ }^{42}$ Missionaries were not

${ }^{41} \quad$ VOC 3779 (1785-88), f. 5732-3.

$4^{2}$ Castro 1867:89-91. Textbooks usually date the beginning of this rebellion as 1781, but a document printed in Castro 1867:292 suggests that it started at some point between 1776 and 1779. Oral traditions recorded in the late twentieth century are ambivalent about the exact relationship between Luca and Viqueque. While Luca was considered to have a symbolically subordinate position vis-à-vis Wewiku, Viqueque was beneath Wehali in terms of status. In one version Luca had a position of precedence vis-à-vis Viqueque, but the latter was not included among the four liurai who were under Luca's authority (Spillett 1999:289-305). 
always supportive of the Dili government; they sometimes took the side of the locals, to the point of playing an active role in armed resistance (Visser 1934:163). This may not be so hard to understand, for the quality of colonial governance at this stage was quite poor. An ex-governor wrote in 1795 that most of the governors were lethargic people who did not have the requisite military or political skills. The officers tended to be criminal figures sent from Goa, who re-enacted their misdeeds on Timor, irritated the princes and conspired against the Estado. In spite of all this, the princes still took great pride in being vassals of Her Majesty (Thomaz 2001:122). The Count of Sarzedas, a viceroy of Goa who in 1811 wrote a set of instructions regarding Timor, had few illusions about the work of his compatriots there: 'the vexations, injustices, stealth and despotism practised in these islands have occasioned these uprisings, and this is shown by the general insurrections of the entire establishment which are undone by the simple arrival of the new governor. ${ }^{\text {'43 }}$ The 'rebellions' in the early Dili period were, however, less frequent than during the Lifau epoch.

Catholicism had long been a binding symbolic force, but by the late eighteenth century the missionary project was dwindling. The Portuguese mission in Asian waters declined for a number of ideological reasons, and Timor was affected accordingly. The number of Dominican padres had shrunk from eighteen in 1740 to merely eight in 1804; in 1811, one single cleric remained. The results of the religious seminaries established in Lifau and Manatuto in the mid-eighteenth century are basically unknown, and no indigenous Timorese priest appears in the sources until the nineteenth century (Serrão and Oliveira Marques 2006:429-30). Under these circumstances it is remarkable that Christianity persisted at all. In 1856, two years after the lifting of a long interdict on religious orders, 22 princedoms out of circa 50 had Christian communities, which together amounted to perhaps $2 \%$ of the population of Portuguese Timor (Durand 2004: 48-50).

On the other hand, the early Dili government finally saw an end to the old enmity that had existed between White and Black Portuguese. In view of the weakened position of the latter, there was not much left to fight over, and their Portuguese identity demanded a degree of contact with the wider world of Portuguese Asia. Governor João Baptista Vieira 
Godinho (gov. 1785-1788) managed to make the first move, and Pedro Hornay (ruled 1777-circa 1795) was described by the Dutch as the most civilized and agreeable figure among the Topass elite. Pedro now swore obedience to Her Majesty and promised to defend Dili and provide it with provisions. In return, he was officially appointed tenente general of the province of Servião; as it stood, the title was by this point obvious fiction. At the same time his in-law in the Larantuka princedom, Dom Constantino Belantran de Rozari, submitted to the Estado. ${ }^{44}$ Oecusse proved to be a self-willed but generally loyal and occasionally even helpful client of Dili for the remainder of the colonial period.

The economy of the small Portuguese establishment remained as cumbersome as ever. The principal means of taxation, the fintas, would be levied on Timor until 1906, but the income derived from it decreased sharply after the great rebellions of the 1720s and 1730s. After 1785, the Estado recompensed some of these losses by reorganizing the system of customs fees, but nevertheless, events in South Asia did disturb the trade. When the British conquered the lands of Tipu Sultan of Mysore in 1799, they found good resources of sandalwood, which were better and more conveniently located than the Timorese resources (Serrão and Oliveira Marques 2006:427; Castro 1867:219). Whether this decline disadvantaged the Timorese is debatable, though, as for two centuries, the precious wood had brought endless strife and probably few blessings to the inhabitants of the turbulent island.

\section{CONCLUSIONS: CULTURES IN CONTACT}

Thus, the Napoleonic Era is where we will leave our discussions of the two early colonial networks. A weakened Dutch enterprise in the west balanced a somewhat stabilized Portuguese establishment in the east, an establishment that had managed to co-opt its old mestizo enemies. Outside the restricted hinterlands of Kupang, Dili and Oecusse, the majority of the perhaps 200,000-strong Timorese population led lives that were at best (or at worst) indirectly affected by the stranger lords.

This is not to say that the Timor and Solor area remained unchanged by two centuries of early-colonial activity. Anthropologists have dis-

44 Castro 1867:212. A Dutch report (VOC 3810 [1789], f. 73) rather credits the next governor Nogueira with visiting Oecusse and bringing Pedro Hornay over to the Estado camp. 
cerned an interesting ability of the societies in the eastern archipelago to integrate foreign influence in spite of their typically 'traditional' character. ${ }^{45}$ This includes very basic means of comfort and nutrition that latterly depended on overseas connections. Maize was introduced by the mid-seventeenth century and has been a staple food ever since; as such it was a mixed blessing, since linguistic evidence suggests that the Timorese diet was more varied in earlier times (Fox 1991a:254). Coffee had been introduced by 1734 , although its intense cultivation only began in the early nineteenth century. ${ }^{46}$ High-quality tobacco was grown in large quantities by 1772, probably for indigenous use (Lombard-Jourdain 1982:91). Contact with foreigners also had cultural implications, influencing for instance outward appearances: while early accounts suggest that commoner women went virtually naked, they covered up most of their bodies from at least the eighteenth century (Lombard-Jourdain 1982:97). The Christian impact, often ridiculed as superficial, should not be disregarded since selective pieces of material culture, habits and symbols trickled down via the partly Christianized elite. This coincided with trade which, it should be noted, was mostly carried out in non-European keels. Clothes from South Asia and elsewhere were in great demand and slowly changed fashions and the now-famous weaving traditions. Household utensils such as advanced pottery and iron tools could not be manufactured locally but also had to be imported.

The organization of society and warfare was also affected. The written word was restricted but not unknown, and the surviving corpus shows that letters in Portuguese and Malay were seen as important documents, detailing for instance appointments and debts owed. ${ }^{47}$ While the basic traditional structures of governance may have changed little, they were infused with Western-derived symbols. Titles like brigadier, colonel, emperor, and so on, may not have meant that the corresponding administrative functions were actually carried out, but they were an important part of the legitimization of the indigenous elite. For example, the Dutch denomination keizer (emperor), originally reserved for the lord

\footnotetext{
45 The argument has been advanced by the well-known Dutch anthropologist F.A.E. van Wouden (1968); see also Yoder 2005:111; Ospina and Hohe 2002:27.

$4^{6}$ Matos 1974a:172. An attempt to introduce coffee in the Amarasi kingdom is referred to in ANRI VOC:4059, Missive, Batavia to Kupang, 17-2-1809.

47 Apart from these so-called Maucatar letters (Stukken n.y., H 693, KITLV), see also the Malay documents pertaining to Pitai, a sub-division of Greater Sonbai, in Middelkoop 1968:85-7. These date from the $1760 \mathrm{~s}-1790 \mathrm{~s}$.
} 
of Sonbai, had been reduced in value by this time as it was appropriated by an increasing number of rulers. During the late colonial period it was used, among others, by the lords of Amfoan-Timau, Amanuban and Insana, and foreign objects of authority, such as drums, halberds, tongkat and flags, were kept as sacred heirlooms of the princedoms (referred to by the Indonesian term, pusaka).

Also, it should not be forgotten that Western technology changed the way in which warfare and conflict took place. Firearms were rare, even among the closest VOC allies, in the seventeenth century, but their presence gradually spread. There was no indigenous manufacturer, meaning that the weapons were always imported, but they seem to have been ubiquitous by the nineteenth century. Bows and arrows fell out of use, as did shields - the Atoni did not even have words for these items by the twentieth century (H.G. Schulte Nordholt 1971:346). The dissemination of modern tools and weaponry meant that new possibilities to assemble political power were opened up, and this may have strengthened the dominance of Atoni ethnicity in West Timor (Fox 1988:269). Precisely this may also be one factor behind the military upsurge of a few kingships, such as those of Sonbai and Amanuban, in the late eighteenth century; an atypical feature in the traditional political system that did not ultimately lead to an actual process of state-building. The taking of slaves was a further factor that depended on Western technology and presence. Sizeable numbers of slaves could be shipped away on European keels, and somewhat smaller ones on Chinese and Makassarese crafts. This action doubtlessly encouraged warfare, as did the mutually hostile alliances centred on foreign or semi-foreign establishments like Kupang, Lifau and Tulang Ikan-Animata.

What was the nature, then, of these alliances? They originated in blood-oaths which implied fraternal bonds but also precedence, and which could be perceived as, or transformed into, a lord-vassal relationship. As Timorese and foreign perceptions of the oaths differed, this could cause friction, but the outcome might also be one in which lasting bonds of loyalty were forged. The Count of Sarzedas made a sarcastic statement in 1811, quoted in Castro (1867:218), summarizing the last century of Portuguese overlordship:

the Timorese are the best vassals and the best Christians. They are the best vassals since they recognize the sovereignty of their legitimate sover- 
eign, while they are governed by men who humiliate them in every way as the circumstances permit without the forces to keep them in obedience. They are the best Christians since they still recognize the evangelical truths without having clergymen who direct them. A nation which unites two such qualities deserves the particular care of our august sovereign.

The case of the Kupang sphere is similar, though even more pronounced in its characteristics. Despite the, at times, poor leadership of the $o p$ perhoofden, and despite numerous cases of extortion and vexations by burghers and administrators, there were almost no uprisings against the Company. Although the words of the viceroy contain rhetoric exaggeration, they do highlight a striking characteristic of Timorese history. Small, sometimes negligible European groups were able to remain in situ for hundreds of years and to exert their influence over large parts of the island. There were bonds of loyalty and deference in place that in the case of the Dutch lasted for periods of time, and in the case of the Portuguese were renewed from time to time.

This situation is defined by two characteristics that are typically Timorese. The first is the 'stranger king' syndrome, which has been explored in a number of Southeast Asian contexts. Shared ethnic identity was not necessarily a unifying factor (Henley 2002:53); on the contrary, one can see that the Minahasa, Minangkabau, Malays, Balinese, and so on, were engaged in ceaseless domestic hostilities during the early colonial period that has been studied here, and, therefore, did not construct a bona fide state. As the preceding chapters have clearly proven, this was the case in the Atoni and Tetun territories, and probably also among the less known Galoli, Makassae, Mambai, and so on. Shared language, kinship and barlaque exchange were not sufficient to construct organizations that could enable conflict resolution at the level of the princedoms, and often not even below that level. As an outsider, the Dutch opperhoofd, the Portuguese governor, and - albeit to a lesser degree - the semi-foreign Topass leader had the potential to foment such organization. That they, as outsiders, did not fall under the adat meant that they had no interest in kinship constellations, thus not making claims and counterclaims. Opperhoofden and governors were normally brought in from outside of Timor, would not stay for more than four or five years, and represented the distant but prestige-laden lordships of Batavia and Lisbon. Although they could be quite rapacious, their coming and going was predictable, 
and the more foreign they were, the more likely they were to successfully resolve conflicts (Henley 2002:55).

This would work for as long as there were fixed arenas of interaction and negotiation between the stranger lords and their subordinate allies or clients. It was successful for the Dutch, who had a manageable area in westernmost Timor to look after up until 1749. The vergaderingen between the opperhoof $d$ and his council and the five allies were normally held within an atmosphere of consensus, but on several occasions the allies could press Father and Mother Company to make concessions. The small Dutch community was completely dependent upon the maintenance of the system in order that they remain on Timor. Though frequently at odds with each other, the allies nearly always let the opperhoofd intervene in order to settle the issue before bloodshed had actually taken place. The expansion of the VOC sphere post-1749 immediately illustrated to the Dutch and the five allies that matters were not so easily resolved on a Timor-wide or even West Timor-wide level.

The situation was somewhat different for the Portuguese mestizo community living on Timor. The Hornays and Da Costas were stranger kings in the traditional Southeast Asian sense: their ancestors had once migrated from elsewhere. Still, they were born in East Flores or Timor and always remained in power until their deaths, thereby developing dynastic dynamics. Acting on behalf of the king of Portugal and in the name of Catholicism, the Topasses posed as a military Portuguese subtribe, while at the same time remaining securely anchored in the local Lamaholot and Timorese cultures. Up until 1702, they were able to obtain the partly voluntary deference of the various Atoni princedoms which they managed to keep in check in spite of occasional clashes. Their late and brutal subjugation of the eastern parts of the island in 1668-1677, however, meant these areas were never stabilized and they willingly defected when the opportunity arose.

Finally, the Estado da Índia was able to quickly gain a following in East Timor after 1702, helped by the mediating authority of Catholic priests. As they had wider areas to attend to than their Dutch counterpart in Kupang, their management was far more turbulent, and was aggravated by the hostilities of the rival Dutch and Topass stranger lords. Although their presence was often justified by extremely tenuous means, they always managed to prevail in their activities. Rather than being a result of the desperate endurance often shown by Portuguese outposts in 
Asia, or the continuous support of Macao, this is testimony to indigenous preferences. Especially when the fintas dwindled into insignificance after the great rebellions, the innumerable princedoms of East Timor saw the advantage that could be gained by having an external force in control, as pointed out by the able governor José Pinto Alcoforado e Sousa (gov. 1815-1819) (quoted in Castro 1867:295): 'The Timorese have preserved us [tolerated our presence] until now due to their interests, since when they make war against each other [...] and when they are exhausted or if one party has the advantage in the conflict, the oppressed party requests that the town [Dili] [acts as an intermediary] to make peace among them - the terms of which are almost never carried out for lack of active force.'

At this point it should be remembered that the situation between the Portuguese, the Dutch and the Timorese population was often one of near open hostility, as observed by a French visitor in 1772 (quoted in Lombard-Jourdain 1982:96): 'They generally detest the domination of the Portuguese who make them lack everything and maltreat them through their robberies and vexations. They only seem to need a support in order to throw off the yoke; they obey them through habit and fear. They have much more fear for the Dutch because of their cruelties and do not like them at all.' The two quotations above seem to contradict each other, but in fact they view matters on two different levels. The Estado and Company servants who ended up on Timor were not always the best ambassadors of the mother countries, but that did not detract from their important structural function. In the Timorese world of perpetual small-scale violence, what people desperately needed was support and security; in the best of situations, this is what the covetous foreigners could offer.

Apart from the stranger king aspect there is a peculiar circumstance which makes Timor unique in a Southeast Asian colonial context. There were three rival centres of foreign or semi-foreign authority on the island for an extended period of time. The opperhoofd and governor acted against each other with regard to trade policy and strategic concerns, although they never openly attacked each other. The Hornays and Da Costas, on the other hand, periodically fought full-scale wars with both European authorities. Nobody could secure a definite victory, and the question remains as to whether such a victory would have been desirable from the local perspective. The entire period from the 1650s onwards 
sees many Timorese who had broken free from an alliance or client-ship with one external power and then submitted to another. Since such political behaviour was also a ubiquitous feature of pre-colonial Timorese polities, it does not contradict the stranger king syndrome. The existence of rival centres of authority made one centre rely heavily on alliances with indigenous princedoms, thus placing the latter in a position whereby they could negotiate an advantage. In various ways, they could pit the external parties against each other.

Do these features therefore make Timor unique in a Southeast Asian, or even wider, context? Can Timor help us to understand the workings of European expansion in the early modern period, or the potential for indigenous response? While the small and isolated nature of the European outposts is somewhat unusual, at least over an extended period of several centuries, the patterns do conform to the results of research carried out on global aspects of colonialism since the 1970s. It has been pointed out that European-Asian relations up until the nineteenth century tended to be centred on partnership rather than hostility. The story of early colonial penetration in coastal Asia and Africa, and in parts of North America, almost always has an element of voluntary collaboration by a local group or fraction, sometimes even by larger communities. As Richard White has shown with regard to the Great Lakes region, Europeans and Indians, in precisely the same period as covered by this book, constructed a system of mutual exchange where negotiations took place and the emergence of new cultural forms began. Only in the late eighteenth and early nineteenth centuries was this superseded by white domination and the suppression of native groups (White 1991). Small European outposts around the globe could survive thanks to indigenous people who hoped to benefit from their presence. Moreover, the role of European entities as arbiters or mediators in a politically complex system has been demonstrated for central and densely populated areas such as Java. The Dutch of the VOC period have been characterized as 'reluctant imperialists' whose expansion was conditioned as much by local demands for assistance as by economically motivated design. ${ }^{48}$ In that way, the roots of colonial governance are to be found within Asia, Africa or, in some cases, North America as much as in Europe itself. Early-colonial social and political manifestations on Timor offer a poignant example of

$4^{8} \quad$ Kwee Hui Kian 2008. Frank (1998) emphasizes the relative lateness of European global economic leadership, the full impact of which was only felt in the nineteenth century. 
historical processes that in various ways are found in many other locations where colonial power relations evolved.

To conclude, Timor in the seventeenth and eighteenth centuries becomes part of a model which only partly justifies the term colonialism. The indigenous societies were only marginally, or indirectly, transformed through this lengthy period of external impact, and none of the plans for intense commercial cultivation had come to fruition by the nineteenth century. It was only in the twentieth century that the governance of the old princedoms and the traditional settlement pattern was broken up by a new and thorough colonial apparatus. Kupang, Lifau, Animata and later Dili were just some of the numerous players in the quest for power that affected the strife-torn island. They were components of shifting alliances, alliances over which the Dutch and Portuguese could not fully wield control, and many of the so-called rebellions can just as well be termed factionalism. At the same time, the external centres were colonial in nature. Due to their vastly superior technology, their modern organization, their means of physical transportation and trade, and their inclusion in larger, even global organizations of commerce and military power, they were secured a lasting role that had both brighter as well as darker implications for the peoples of Timor. 